\title{
Key Performance Indicators of Supply Chain Retail Training Manpower Development and Employee Performance in an Organisation
}

\author{
Asiri Mohammed Abdulrahman $\mathrm{Y}^{1^{*}}$, Liu Cheng ${ }^{2}$, Liu Xiangdong ${ }^{3}$, Alotaish Mohammed Saud $\mathrm{M}^{4}$ \\ ${ }_{1,2,3}$ Department of Management Science and Engineering University of Science and Technology Beijing, Beijing, China \\ ${ }^{4}$ The Commercial Consul at the Saudi Embassy in China
}

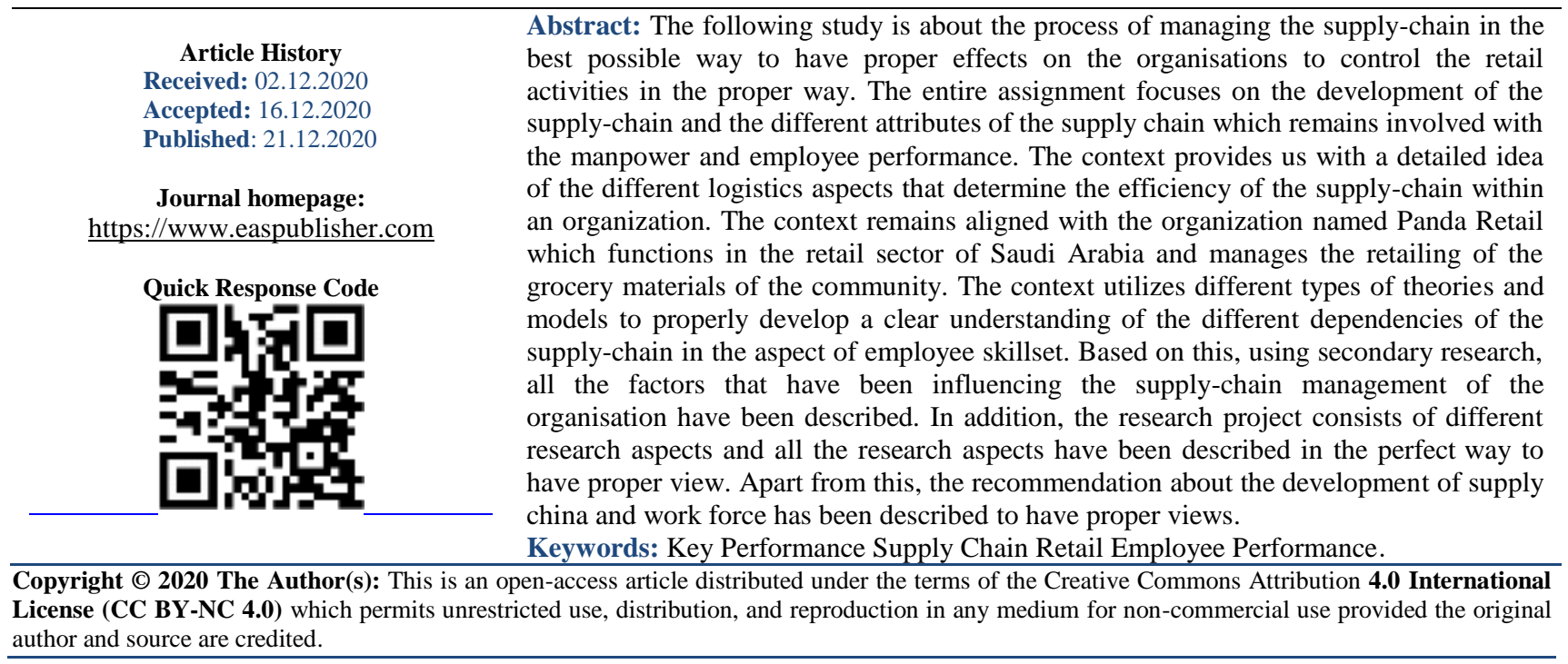

\section{INTRODUCTION}

Supply chain is one of the major operations undertaken by a firm in order to segment the different types of requirements that are highly functional for the supply chain of an organization. In order to maintain the supply chain at a proper scale, we will be focusing on the different attributes like manpower development and employee performance in in order to understand their importance of maintaining them for the sustainable development of the organization [1]. The Panda retail company has been selected as an instance for the organization-based analysis that will be conducted to study the different aspects of the supply chain.

\section{RESEARCH AIM}

The main aim of this context is to identify and study the different key factors of the supply chain like the manpower development and employee performance so that the different types of impacts can be assessed within the organizations present in Saudi Arabia.

The research will involve the identification of the major supply chain attributes and determine the different types of factors in terms of logistics that will be utilized for the enhanced analysis of the impacts encountered by an organization [2]. It is important to understand that the proper identification of the different key factors that put a significant impact on the abovementioned attributes and helps in determining vital aspects of the organization allows for minute details on the performance of the employees.

\section{Research ObJectives}

- To develop an elaborate understanding of the different aspects that is involved with the supply chain of the retail based-companies like Panda Retail operating in Saudi Arabia.

- To involve the critical details and will maintain a proper analytical format so that each and every factor in the supply chain of the retail industry can be analysed in accordance with the different parameters of the company

- To focus on the impacts faced by the organization's functioning in the supply chain due to the manpower development and employee performance.

\section{RESEARCH QueSTIONS}

- What is the impact of focusing on the training of manpower development with respect to the economic standing of an organization? 
- What is the impact of employee performance on the sustainable development of the supply chain within an organization?

- What are the the internal and external factors that involve the development of the firm in the aspect of the logistics network that largely impact the functioning of the supply chain?

- What are the positive and the negative factors of promoting manpower development in influencing the demand shift of the consumer base?

\section{Problem statement}

The major problem faced the supply chain in the retain is the lack of employee training that hampers the performance of the employees at a massive scale. The poor performance of the employees in Saudi Arabia due to inadequate training has led to a significant amount of reduced productivity that has been observed to deplete the entire economy of the business ground. The lack of training and experience in the field work of the employees has also donated a significant amount of ill reputation within many organizations that have resulted into lower customer concentration on the firms [3]. The Panda Retail Company which involves the market place for all kinds of grocery needs, have been majorly affected because of this problem and the company has also recorded as one of the lowest sales records since its course of operation. The inability to identify the key factors that lead to the development of the employee has led to a significant downfall in the overall establishment of the comapnaty.

\section{Justification of the study}

It has been identified in the recent days that the supply chain majorly handles the market demands and the established companies usually set the trends and control the inflow and the out flow of the products available; in the market [4]. The entire logistics network majorly relies on the efficiency of the employees and their ability to grow within a system that would facilitate the organization with higher productivity that will allow the development of the firm in segmental manner. The study will majorly contribute to the different roles played by the employees in the development of the logistics network and the supply chain that involves the firm's establishment on its business grounds and determine the scope pf growth that will be parameterized on the basis of employee performance and manpower development.

\section{Structure of the paper}

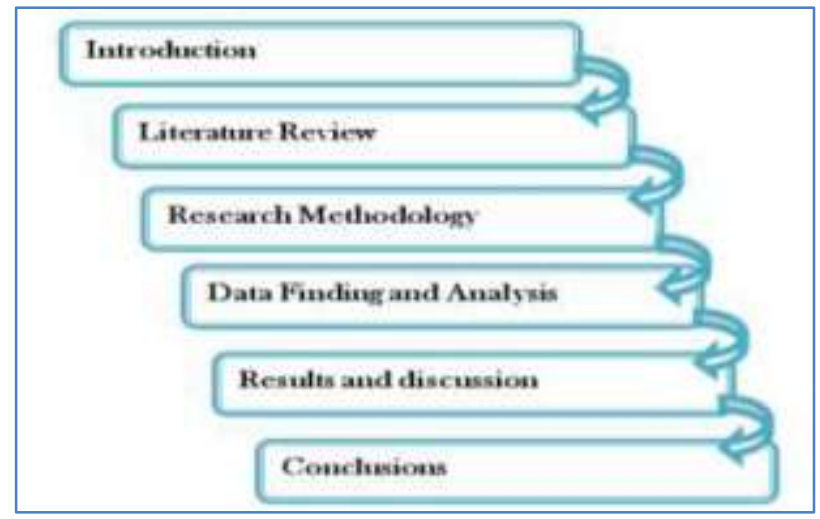

Fig-1.1: paper structure

(Source: Created by Author)

\section{LITERATURE REVIEW \\ Conceptual framework}

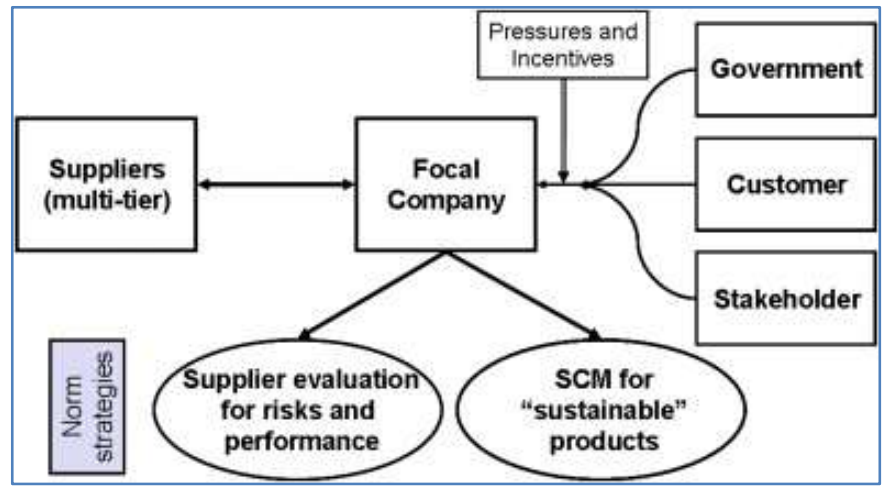

Fig-2.1: Conceptual Framework of Supply chain Source: Mabrouk, N. 2020 [5]. 


\section{Overview of the scenario}

It is important to understand that the entire department of the supply chain is largely managed by the manpower functioning within an organization and the productivity and the sales ratio majorly decides upon the different types of performance provided by the employees as well as the collective effort put by the entire manpower [6]. This concept remains solely centred with understanding the different kinds of necessities required by the supply chain to improve its productivity and enhance its distribution network in order to increase the establishment of the organization. In Saudi Arabia, it is important to understand that the functionality of the organisation in the supply chain relate remains solely centred with the concept of the different types of functional and the non-functional concept that hamper the several operations of the organization. The focus of the study is to understand the key concepts of the supply chain retail and how the development of the manpower and the employee performance impact on the establishment of the Panda retail company. Considering that the organization majorly functions on the grocery aspects, it is important to understand that the suppliers for the grocery items play the major role in the trading and the revenue generation that becomes a major part of the organization's sustenance.

\section{Importance of supply chain in the economy maintenance of market}

The retail stores usually deploy a large amount of manpower for gathering and developing the different kinds of resou4rces and gathering clients that promote the retail-based partnership with the firm so that the entire inflow and the outflow of the financial assets remain under control [7]. Saudi Arabia maintains a highly dynamic economy c framework that allows any newly developed organization to establish its foothold in in its operating market. Most importantly the logistics network of the supply chain majorly functions on the relations that have been built with the people providing the retail materials for sale and improves on the development of a large-scale referral network that involves the engagement of the consumer base at a large scale. The supply chain of the retail helps in the development and the removal of demand of a certain commodity and is able to set trends that largely influences the consumer base and increases the concentration of the potential customers which is extremely important to maintain the dynamics of the economy set up by the firm.

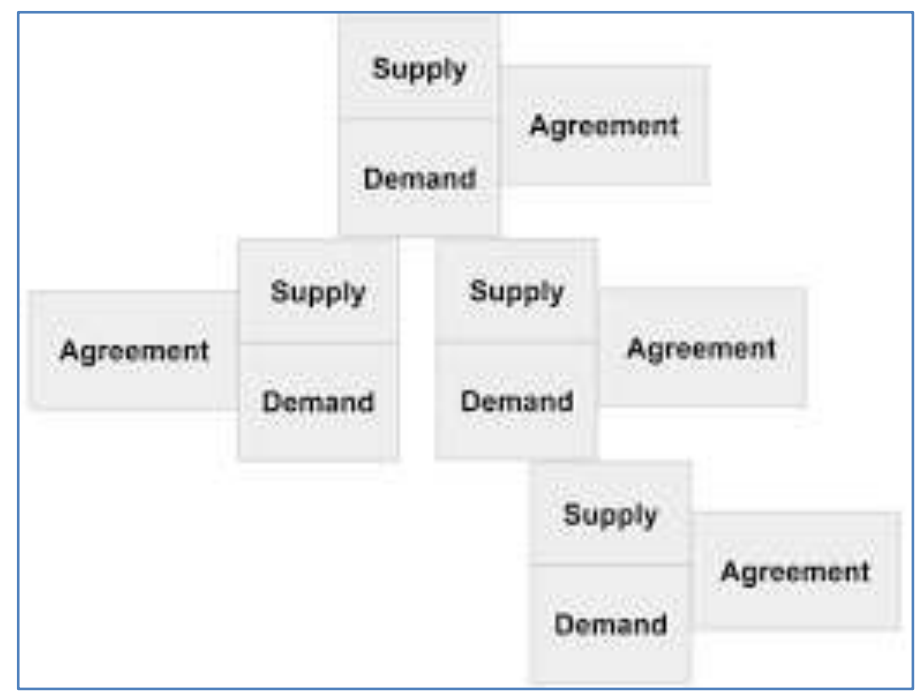

Fig-2.2: Functioning of Supply Chain

Source: et al., Brundage 2017 [7]

\section{Impact of manpower development on the conversion rate}

It is important to understand that the conversion rate is one of the major parameters that acts as a key performance indicator in the supply chain retail. It is important to understand that the facilitation of the conversion rate in the retail-based supply chain largely depends on the employee engagement with the customers [5]. The ability to increase the productivity and the sales ratio largely resides on the performance of the employees that have been deployed for sales. The manpower development must be regulated by an organization in order to properly facilitate the different kinds of necessities required by the customers and increasing the staff members who remain directly related with the sales can improve the customer engagement. An increased engagement would amplify the chances of sales per unit which becomes a highly determinant factor in the increase of the revenue generation due to increased conversion rate. It is important to understand that providing the staffs with the necessary skillset becomes a vital part for increasing the performance of the employees that lead to a better establishment of the firm in the operating market [8]. The manpower development and training allow an 
organization to perform at aits full potential at the cost of some investment of financial assets for the training.

\section{Relation of customer retention with employee performance}

Retail organizations around the world majorly rely on the different types of customer's relationship on the basis of which the entire revenue generation mapping is done. The retail industry no only has to maintain relation with the direct customers but also have to retain partnership with the suppliers and treat them as a valuable candidate in order to maintain the productivity of the firm. For such reasons, organizations deployed certain personnel who specialize in the customer and client relationship and mainly function on the domain of retaining the clients that provide a large sum of revenue to the firm. In Saudi Arabia, it can be said that the overall process of the firm has a large impact on the several types of functionality undertaken by the employees in the management of the customer relation. Considering that the customer relationship forms as the root of any consumer retention tactics, it becomes highly important for the employees to train on the key factors that determine the ability of the consumer to stay aligned with the organization [9]. The basic training of the employees involves understanding the demand of the consumers and how they can engage their clients on aligning the organizations objectives with the demand of the market set by the consumer base.

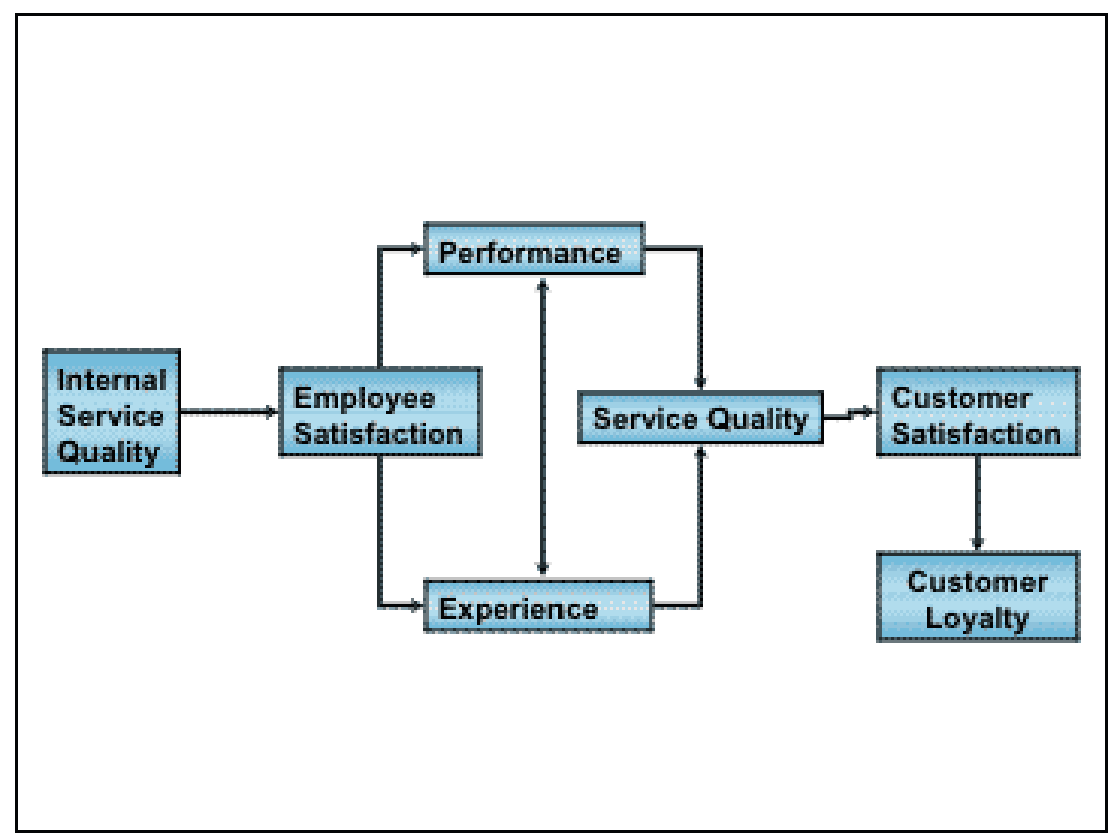

Fig-2.3: Customer retention mechanism

Source: Rehman et al., 2020 [9]

\section{Assessment of retail-based supply chain with respect to inventory turnover}

Inventory turnover also works as a key performance indicator for the firm and allows the organization to assess its gradual progress in it operating market in its due course of operation. It is important to understand that the entire assessment process of the organization involves a severe amount of workforce comprising of highly trained professionals who can majorly maintain the entire format of the firm's sales ratio assessment. It becomes important to understand the change in the inventory turnover allows the any real based firm to assess its supply chain and logistics at a frequent time period and enhances the organization with significant reports that allow the organization to regulate its productivity with respect to the sales [8]. The inventory turns over allows the organization to gradually develop a contextual understanding of the different kinds of functionalities that the organization needs to undertake and how the manpower should be trained in order to improve the performance which will positively impact the entire productivity. Inventory turnover works as an indicator as well as aa parameter for the milestone achievement necessary for understanding the progress of the firm. In Saudi Arabia, it can be mentioned that the entire retail business runs on an intricate framework comprising of different assessment tools like inventory turnover which have been developed in order to assess progress of the organization in its due course of operation.

\section{Efficiency of implementing supply chain management within an organization performance}

The supply chain management is utilized for the development of the entire mechanics of the distribution network functioning within any retail-based firm. To understand the efficiency rate with respect to the organizations supply chain, it is important to utilize several theories that help in assessing the parameters required for the development of the firm [10]. 
Agency theory- This theory is utilized to understand the concept of logistics in the distribution network of the supply chain. The major section of this theory focuses on the key factors like bounded rationality, asymmetric information and goal conflicts. It is important to understand that this theory contributes in understanding the different types of functionalities that involve the development of the manpower and the e employees which enhances the performance of an organization. For instance, it becomes highly reciprocated in terms of the operations undertaken by the organizations facilitating the supply chain and put a high influence on the individual performance of the employee involved in a certain task. The major attribute of the agency theory lies in the division of the labours that influences the proper distribution of the task among the employees on the basis of their skillset that yield to high level of performance [11].

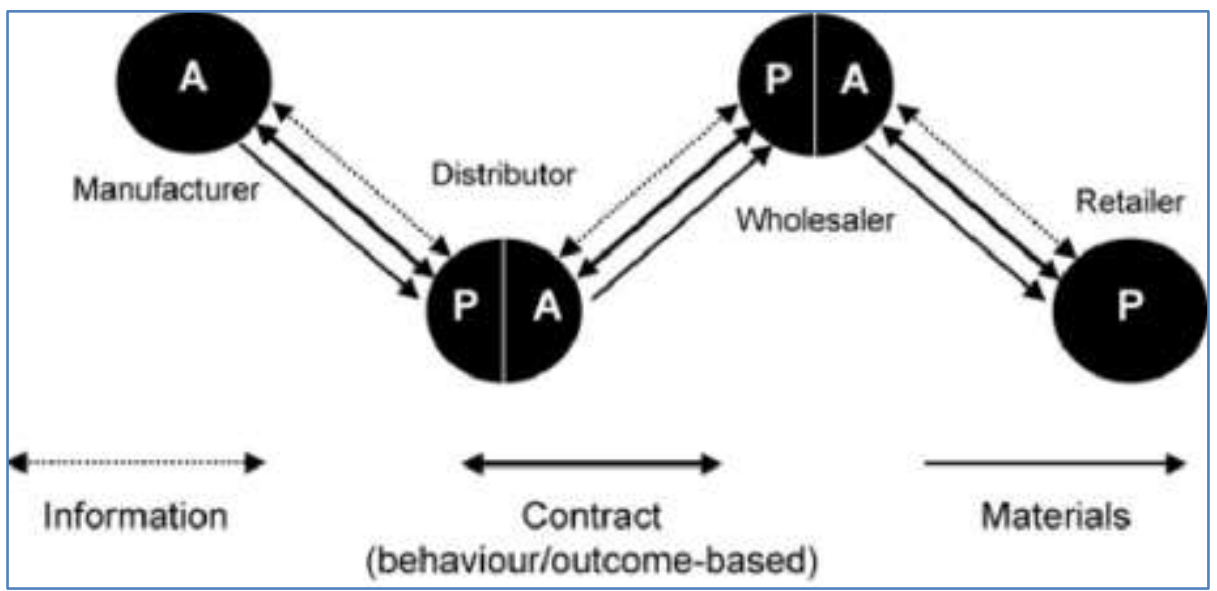

Fig-2.4: Agency theory

Source: Panda and Leepsa, 2017[11]

Network theory- Networking theory majorly functions on the basis of two traits, that is bounded rationality and trust. This theory involves a very practical method of analysing the requirement in the supply chain and keeps the ability to assess the static or dynamic network connection maintained by an organization. It can be said that this theory involves the major indicator and performance factors like access control, client relationship and resource management that involves the development of the firm in order to understand the different factors affecting the supply chain of the firm [12].

\section{Necessity of having manpower within supply chain}

Maintaining proper manpower within the supply chain maintains the highest priority within the development of the organization in retail business that allows the company to undertake different types of functionality on the basis of different requirement $s$ from the customers. It can be easy to deduce that the entire mechanism of manpower recruitment relies largely on the different kinds of consumer demands in the operating market [9]. It is important for a retail organization to maintain a sufficient amount of workforce comprising of highly skilled professionals so that the company can yield the best results in order to understand and operate on different kinds of supply chain environments.

\section{Literature gap}

The context of literature review contains a brief analysis of the major factors involving the supply chain but does not relate in details in regards to the other logistic factors that remain co-dependent with the distribution network facilitated by the retail companies. The context also does not provide a detailed analysis of theory mentioned and also fails in proving proper criteria for the implementation of a supply chain framework which becomes extremely vital for having an enhanced understanding of the entire concept. The context also lacks out on the employee performance factor and does not align the productivity and sales concept pf the relate based firm utilizing the supply chain. 


\section{RESEARCH METHODOLOGY}

\section{Research onion}

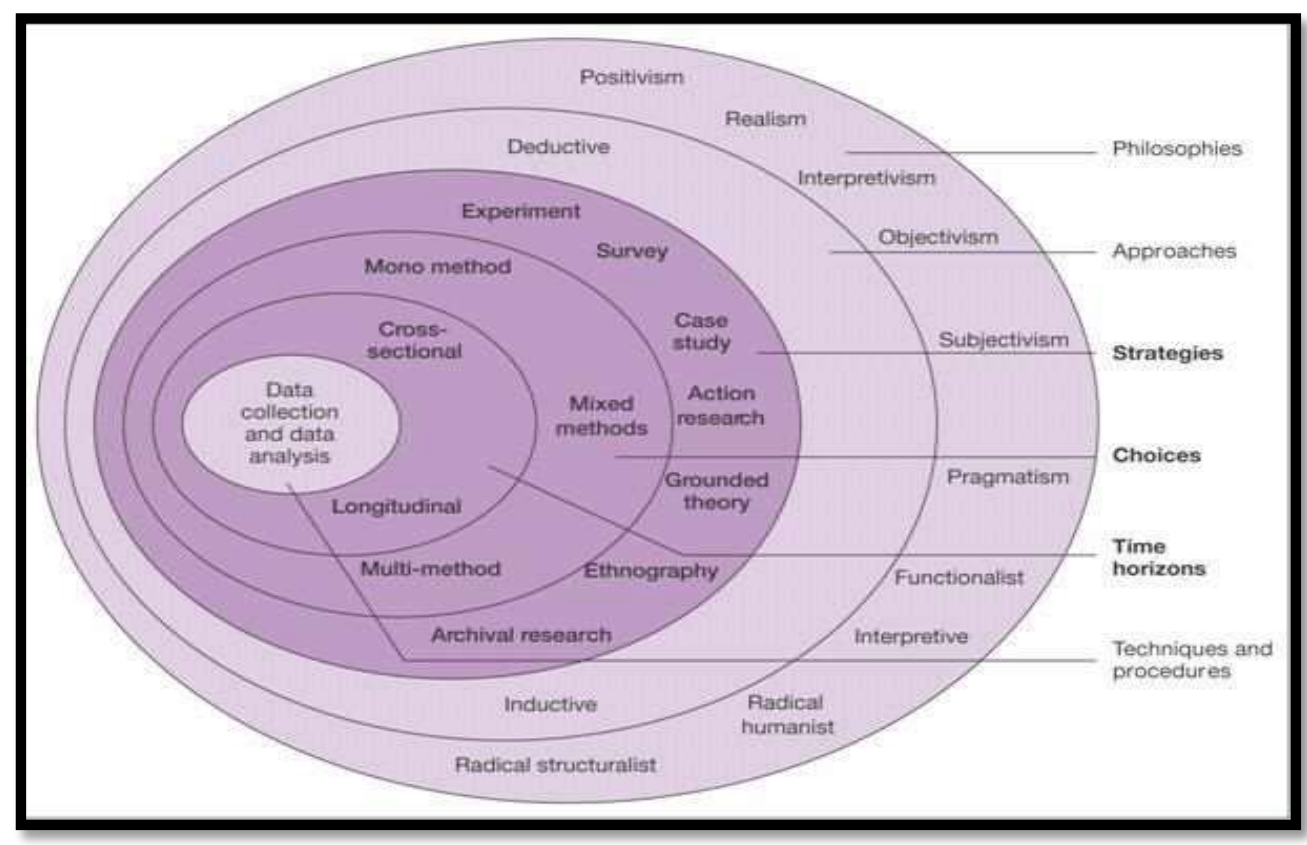

Fig-3.1: Research onion

Source: Strähle and Müller, 2017 [13]

\section{Research philosophy}

Research philosophy is about the process of assessing the total research activities in the best possible pathways efficiency in the processes that are very effective to be conducted to have expected outcomes. In the process of research philosophy, three important factors need to be focused including positivism, interpretivism and pragmatism [14]. In light of this, the positivism will be focused in the process to have effective results in the research findings. On the other hand, the process of research will be conducted by collecting ample amounts of data to make the analysis in the correct way to have positive results. Therefore, to analyse the importance of the supply chain, and the efficiency of the employee performance, respective approaches will be applied to have effective results.

\section{Research design}

Research design is the process of analysing the research components in the perfect way to have absolute benefits in the research process. Based on this, the research process is designed in a way that will be very effective to the researchers to have support in the process of understanding the perspective factors that can be very effective to have a positive impact. The research designs are made of different contents and those are descriptive, correlation, experimental and causal-comparative [4]. In the given context, the researcher has focused on the process of experimental design to have proper support in the process of accomplishment of the following research process.

\section{Research approaches}

Research approaches are very effective to be used in the research process to have absolute results in the data collection and data analysis process of the following research project. There are two major research approaches that news can be used in the following process to have effective results [15]. In the given scenario, the deductive approach has been chosen to conduct the research process in the perfect way. The deductive approach is about the process of performing the process based on the theories that can be playing a significant role in the context. Therefore, using the approaches the following project will be conducted to have effective results and positive impacts on the projects.

\section{Data Collection Methods}

Data collection is one of the most effective processes that need to be conducted to have effective results in the process, as with the help of data collection method effective information can be collected from different sources that are significant. There are two different research processes and those are the qualitative and quantitative method of data collection. In the quantitative approach, the primary method of data collection is used to collect fresh data by asking questions and by taking interviews of the respective respondents [13]. On the other hand, the quantitative approach is about the study of different research papers including the articles and journals. In the given context, the quantitative method of data collection will be used to increase the significance of the research process. 
Therefore, based on this, various types of research papers will be analysed to have effective information in the process.

\section{Data Analysis}

The process of data analysis is another important process that needs to be processed in the perfect way to have effective benefits. In that case, the data analysis is about two respective processes and those are the statistical analysis and descriptive analysis. In the following context, the descriptive analysis will be conducted to have effective results [13]. Therefore; to conduct the descriptive analysis, the thematic analysis will be focussed to have effective results and to identify the respective factors that have been influencing the process on a large scale.

\section{Limitation}

In the following process, the research process has been conducted in the positive way to have effective results to meet the successive stage in the perfect way. In the research process, the secondary research method has been applied to have effective information about the research topic [16]. Therefore, some of the negative impacts of the secondary research methods is that fresh data about the topic cannot be collected and the collected data sometimes cannot be trusted due to the inefficiency of the respective sources. Except this, the internet-based data are fake in several cases, therefore there can be a chance of misconduct in the research activities.

\section{Ethical consideration}

Ethical consideration is one of the most effective parts that need to be focused in the perfectpathways efficiency in the research activities. On the basis of this, the several ethical cats need to be considered to have effective results including the data protection act and the intellectual property rights act [17]. Apart from this, all the data that has been collected will; not be shared with any individual who is not involved in the process. These are the ethical considerations that need to be followed to have effective results.

\section{Data Findings AND ANALYSIS}

\section{Secondary data finding}

\section{Thematic analysis}

\section{Theme 1: Importance of supply chain in organisational performances}

The supply chain is very effective for the respective organisations to have proper efficiency in the process of developing the organisational structures to have effective results in the business area. In nature of resources based view, the organisational performances can be categorised into three parts and those are environmental, operational and financial performances. In the given context, the maintenance of the operations performances of the supply chain is very effective to the organisation to focus on the respective factors that can be used to improve the financial and environmental performances in the correct pathways efficiency [18]. Supply chain is very effective for the organisation to have proper efficiency in the process of managing the manufacturing process, as the conversion of the raw materials into effective products and services that are used in the commercial way in the organisation to conduct the business process in the respective market. In light of this, the use of supply chain operation reference (SCOR) can be playing an effective role in the area of maintaining the supply chain network of the organisation test in the respective market to have effective results [19]. In addition, use of the SCOR can be very effective to the organisation to point out the five key performance indicators and those are reliability of order fulfilment, responsiveness, agility and flexibility, cost containment and asset management. Therefore, effective management of these five factors can be very beneficial to the organisation to have absolute efficiency in the process of business.

\section{Theme 2: Importance of supply chain optimisation framework development}

DMAIC refers to the data driven outline of an improvement cycle that needs to be implemented in the organisation to have effective results in the business process to have effective control of the supply chain related factors in the best possible way. The DMAIC is very effective to be used in the organisation to have effective efficiency in the process of implementation of the lean principle in the supply chain [20]. It can also be used in the process of managing the use of six sigma approaches in the organisation to improve the quality of performance of the respective supply chain [21]. The DMAIC cycle can also be used in the process of managing the management of the key performance indicators in the organisational process to have efficiency in the area of supply chain network to have expected profits in the process. Apart from this, the respective model is very effective to the business process to manage the aspects of the information and communication system in the organisation to have effectiveness in the process of business in the best possible way.

\section{Theme 3: Supply chain and product characteristics}

In present days, the implementation of the digital model is very effective at improving the process of business in different ways, which can be very productive to the respective organisation to have appropriate efficiency in the business process [22]. The impact of digital; technologies are very high in the retail industries to enhance the quality of the performance and to have proper conduction of the business aspects in the respective area. It is very essential to the respective organisation to manage the effectiveness of the supply chain to have proper support in the area of managing the major characteristics of the respective products that can be very effective to the organisation to have 
appropriate support in the process [23]. On the basis of this, effective control of the manufacturing process, respective machineries and the employee performance can be very effective to the organisation to have effective support in the supply chain activities. Apart from this, digitalisation is becoming one of the most effective trends of the organisation to have proper support in the process of customer engagement area for the respective restrain industries.

\section{Theme 4: Impact of supply chain performance measures on organisational performance}

Measurement of the supply chain performance is very effective to the organisation to have proper support in the process of business activities for the respective industries. In that scenario, the factors such as the quality, dependability, flexibility and cost need to be measured to have proper efficiency in the process of supply chain of the respective organisation [24]. In that area, attentive focus on the market share is very effective to the respective retail industries to have proper support in the process of managing the supply chain activities and the respective costs to have expected results in the business process. In addition, the developments of the flexible strategies are very effective to the respective industries to improve the performance in the respective market to have proper support in the process. As opined by Gawankar et al., [25], the improvement of the supply chain network can be improving the performance of the organisation to have proper support in the process of managing the competition of the respective market.

\section{Theme 5: Effective skills and competencies for the supply chain professionals}

Skills and knowledge of the respective professionals are very essential to have effective conduction of the supply chain related operations in the retail industries. In this context, the effective management of the competencies of the employees are very effective to the organisation to have absolute results that can be used in the process of managing the business process in the perfect way. In the given scenario, the learning agility, information literacy, intellectual autonomy and self-management is the key to have proper efficiency in the process of managing the supply chain and to have proper support in the organisation to have successive results. In addition to this, the communication skills of the respective individual needed to be improved to have enhanced efficacy in the process of working in any team to enhance the production capability [26]. Initiative and enterprising skills are also a very effective part of the employee's skills that needs to be improved in the perfect way to have effective efficiency in the accomplishment of the respective responsibilities for the retail industries. On the other hand, the respective employees of the organisation need to be very observant to the organisational activities to have absolute efficiency in the process of following the rules and regulations of the organisation to have an effective workplaces environment.

\section{Theme 6: Security and privacy of the supply chain network}

It is very effective to the organisations to manage the security and privacy of the supply chain network to have proper efficiency in the respective operations. In the present days, the supply chain is being managed through the effective implementation of the IT systems in the organisation to have enhanced efficiency in the process of conducting the operations of the supply chain management [22]. Therefore, different types of technologies are used in the organisations to improve the business process and to have proper customer engagement. In addition to this, the maintenance of the security of the It systems and respective networking systems need to be managed in the perfect way to have proper efficiency in the operations related to the business process. In this context, some of the systems have a huge amount of information about the employees and respective customers, therefore all the information needs to be protected to have an enhanced process of operation in the organisation. According to Shahzad et al., [27], the management of the factors like devices, respective configurations, protocols and the communication system can be very beneficial to the organisation to improve the performance of the supply chain and it can boost the profitability of the respective retail industries to have more profit.

\section{Theme 7: Importance of training and development programme in the organisation}

Training and development is considered as the process to be used in the retail industries to encourage and enhance the performance capabilities of the respective employers and managers to have positive results in the process. According to Omoikhudu [28], in the retail industries, to conduct the training and development programmes, it is essential to use the systematic approaches that will; be very effective to the employees to learn and develop the talents and skills in the perfect way to have proper efficiency. In the given scenario, the improvement of the supply chain operation can be performed using the proper approaches of training and development programmes to have absolute efficiency in the respective process.

\section{Theme 8: Criteria for measuring the performances in the organisation in supply chain area}

There are several measuring criteria that need to be focused to have effectiveness in the process of managing the supply chain. According to Gayen [29], the factors of measuring the performances are the effectiveness of the performances, efficiency of the employees, quality of the products and services, time taken to accomplish the task, financial performance and the diversity in the workplace environment. Therefore, these factors need to be managed in the effective 
pathways benefits in the process of business and to manage the supply chain activities.

\section{RESUlTS AND DisCUSSION}

The above context provides a very clear picture on the supply chain of the retail-based forms operating in Saudi Arabia and also provides the differential comparison of the different components used in the logistics and the supply chain of Panda Retail. The research and the analysis provide us with some of the essential statistics that involves a complete observation on the performance of the firm's in different timelines. It can be understood from the above analysis that the entire mechanism remains largely aligned with the work force development within an organization and relies majorly on the person to person performance of the employees [30]. It was discovered that in Saudi Arabia, the retail business contributes towards handling the economy of the country and remains highly aligned with the concept of the employment in mass number in order to meet the demands of the consumer base. The context clearly described the major aspects of the supply chain and how the logistics network is utilized to enhance the performance of the organisation in a large scale.

From the above research, it was observed that Panda retail made a significant amount of change in the supply chain framework that works as a major distribution network for both the customers and the suppliers. Panda retail took the opportunity if the shifting a market and adjusted its inventory on the basis of different demands made by the consumer base in large scale [10]. For the successful utilization of any new framework, in the supply chain, it becomes highly important to train the employees with necessary skillset so that they can perform as per the task assigned. The context utilizes several theories develop the concept of the supply network and the necessary manpower required to regulate the firm on a differential basis and understand the different demand made by the consumer base from time to time. It was also observed that supply chain plays a major part in optimizing the framework that is being utilized for the development of the firm on a daily basis and margins the several revenue generations factors that sustains the growth of the organization. It is important to understand that the entire logistics and the supply chain maintain a high relation with the employee performance and also on the employee concentration present within the organization [31].

In the case of the Panda Retail in Saudi Arabia, it was observed that a properly developed supply chain helps in facilitating a rapid growth of the company. This allows the firm to look for extensive business grounds so that it can grow past its current operating market. It was observed from the analysis that Panda retail thoroughly examined its required manpower and the skill base of the employees and worked significantly on the improvement of those aspects that led to the steady rise of the organisation. Considering that the firm majorly works on the grocery commodities which are utilized for a large-scale consumption, it can be said that the entire mechanism of the supply chain remains highly centred around the concept of providing the distribution on a daily basis [32]. Therefore, these supply chain had to be designed in such a manner that it was highly optimized and utilized a convenient framework so that the employees can perform at their maximum potential leading to a sustainable growth of the organisation. The analysis also provided as with a clear picture on the importance of the employee training which must be facilitated by the firms in order for the company to perform as per the market requirements.

The context laid out a detailed analysis of the skills and the competencies required by the employees in order to execute the tasks present in the supply chain with high diligence. To understand that the entire concept laid out a foundation on the basis of the capabilities of the employees and the skill base required by the employees to performs several functionalities in the supply chain and logistics [8]. The context also described in details the different attributes that allow for a high level of security in the supply chain and how the customer concentration remains directly related to the security aspects of the supply chain.

\section{CONCLUSION AND RECOMMENDATION Conclusion}

From the analysis of the data, it can be understood that the supply chain is very effective to be managed to have effectiveness in the process of business for the retail industries in different sectors. In this context, the implementation of the effective strategies in the supply chain of the respective organization can be very beneficial to have effective profits. In addition to this, the effective management of the supply chain network in the rain industries will be enhancing the manpower of the organisation to conduct different activities in the bst possible way. Therefore, it can be stated that the improvement of the training and development programme can be very effective to the respective organisation Panda retail to have successive results in the process. On the other hand, effective management of the key performance indicators in the supply chain activities will be helping the organisations to focus on the respective factors that need to be managed in the proper way to have absolute efficiency. In that case, it is also important to motivate the employees in the perfect way to have proper efficiency in the process of business and to have proper support in the process of managing the supply chain. 


\section{Linking with objectives}

The objectives of the given research process have been met in the different sections of the following research project in the perfect way.

\section{Objective 1: To focus on the impacts faced by the organization's functioning in the supply chain due to the manpower development and employee performance.}

This has been given in full details in the section of secondary research process through the conduction of the thematic analysis and using the appropriate themes. The following objective has been given proper ideas about the factors that have been influencing the process of development of manpower.

Objective 2: To involve the critical details and will maintain a proper analytical format so that each and every factor in the supply chain of the retail industry can be analysed in accordance with the different parameters of the firm.

This objective has also been provided with appropriate details in the section of data analysis, where all the collected data has been analysed in the proper way to have proper view.

Objective 3: To develop an elaborate understanding of the different aspects that is involved with the supply chain of the retail based-companies like Panda Retail operating in Saudi Arabia.

This objective has been met in the section of literature review to have proper knowledge about the factors that have been influencing the development of the research projects on a large scale.

\section{Future scope and limitation}

The following research has been conducted in the best possible way to have proper results in the area of gathering knowledge about the management process of supply chain. In the following context, collected data are very effective to the research authorities to have proper support in the analysis area. Except this, the research needs to make several adjustments in the process to have effective results in the future works. Therefore, the research needs to be more attentive while collecting the secondary data and in the area of making analysis. Apart from this, to have effective findings the research limitations are needed to be focused to have proper results. On the other hand, the research approaches must be applied in the perfect way to have more effective information that can be used in the research activities to have perfect results. In addition, in the future, the possible theories about the topic must be added to have proper support in the process.

\section{RECOMMENDATION}

There are several recommendations that needs to be focused and those are,
- In order to develop the supply chain, the supply of raw materials must be focused to have effective results. In that case, organisations such as the Panda retain needs to be focusing on the factors that are influencing the supply of raw material.

- Panda retail must be focusing on the efficiency of the employee performance to have effective results in the supply chain management and in the area of having proper support in the process of business.

- It is also essential to the Panda retail to focus on the operational performances of the supply chain to have effective support to the financial and environmental activities in the perfect way. In that case, the organisation must implement digital technology to increase the efficiency of the respective activities on a large scale to enhance the process of supply chain management.

- On the other hand, Panda retail needs to be focusing on the factors such as the product characteristics to develop the respective products and services that will be enhancing the business activities of the organisation on a large scale. In that case, the management of the respective factors about the products needs to be managed in the perfect way to improve the supply chain management to have possible benefits.

\section{REFERENCE}

1. Baba, T., Toth, D. J., Sengupta, N., Kim, Y. J., \& Balla, T. (2019). Phosphatidylinositol 4, 5bisphosphate controls Rab7 and PLEKHM 1 membrane cycling during autophagosomelysosome fusion. The EMBO journal, 38(8), e100312.

2. Moons, K. G., Wolff, R. F., Riley, R. D., Whiting, P. F., Westwood, M., Collins, G. S., ... \& Mallett, S. (2019). PROBAST: a tool to assess risk of bias and applicability of prediction model studies: explanation and elaboration. Annals of internal medicine, 170(1), W1-W33.

3. Kusrini, E., Lukita, M., Gozan, M., Susanto, B. H., Widodo, T. W., Nasution, D. A., ... \& Siregar, Y. D. I. (2016). Biogas from palm oil mill effluent: characterization and removal of $\mathrm{CO} 2$ using modified clinoptilolite zeolites in a fixed-bed column. International Journal of Technology, 7(4), 625-634.

4. Mokhtar, A. R. M., Genovese, A., Brint, A., \& Kumar, N. (2019). Supply chain leadership: A systematic literature review and a research agenda. International Journal of Production Economics, 216, 255-273.

5. Mabrouk, N. (2020). Green supplier selection using fuzzy Delphi method for developing sustainable 
supply chain. Decision Science Letters, 10(1), 6370.

6. Dev, S., Li, T., Phillips, J. M., \& Srikumar, V. (2020). On Measuring and Mitigating Biased Inferences of Word Embeddings. In $A A A I$ (pp. 7659-7666).

7. Brundage, A. (2017). Going to the sources: A guide to historical research and writing. John Wiley \& Sons.

8. Alhamali, R. M. (2019). Critical success factors for green supply chain management practices: An empirical study on data collected from food processing companies in Saudi Arabia. African Journal of Business Management, 13(5), 160-167.

9. Rehman, U., Shahnawaz, M. G., Khan, N. H., Kharshiing, K. D., Khursheed, M., Gupta, K., ... \& Uniyal, R. (2020). Depression, anxiety and stress among Indians in times of Covid-19 lockdown. Community mental health journal, 1-7.

10. Mohammed, M. A., Abd Ghani, M. K., Hamed, R. I., Mostafa, S. A., Ahmad, M. S., \& Ibrahim, D. A. (2017). Solving vehicle routing problem by using improved genetic algorithm for optimal solution. Journal of computational science, 21, 255-262.

11. Panda, B., \& Leepsa, N. M. (2017). Agency theory: Review of theory and evidence on problems and perspectives. Indian Journal of Corporate Governance, 10(1), 74-95.

12. Treiblmaier, H. (2018). The impact of the blockchain on the supply chain: a theory-based research framework and a call for action. Supply Chain Management: An International Journal.

13. Strähle, J., \& Müller, V. (2017). Key aspects of sustainability in fashion retail. In Green fashion retail (pp. 7-26). Springer, Singapore.

14. Dubey, R., Gunasekaran, A., Childe, S. J., Fosso Wamba, S., Roubaud, D., \& Foropon, C. (2019). Empirical investigation of data analytics capability and organizational flexibility as complements to supply chain resilience. International Journal of Production Research, 1-19.

15. Al-Mansour, J. F., \& Al-Ajmi, S. A. (2020). Coronavirus' COVID-19'-Supply Chain Disruption and Implications for Strategy, Economy, and Management. The Journal of Asian Finance, Economics, and Business, 7(9), 659-672.

16. Li, X., Du, J., \& Long, H. (2019). Green development behavior and performance of industrial enterprises based on grounded theory study: evidence from China. Sustainability, 11(15), 4133.

17. Ilyenkova, K. M. (2019). Category management in Russian retail sphere (case of the Ural Federal District). R-Economy. 2019. Vol. 5. Iss. 1, 5(1), 3848.

18. Loon, L. K., Udin, Z. M., Hassan, M. G., Bakar, Z. A., \& Hanaysha, J. R. (2017). The power of organizational innovativeness in shaping supply chain operational performance. Advanced Science Letters, 23(9), 8579-8585.

19. Delgado, M., \& Mills, K. G. (2020). The supply chain economy: A new industry categorization for understanding innovation in services. Research Policy, 49(8), 104039.

20. Alzoubi, H., \& Yanamandra, R. (2020). Investigating the mediating role of information sharing strategy on agile supply chain. Uncertain Supply Chain Management, 8(2), 273-284.

21. Farsi, M., Bailly, A., Bodin, D., Penella, V., Pinault, P. L., Nghia, E. T. T., ... \& Erkoyuncu, J. A. (2020). An Optimisation Framework for Improving Supply Chain Performance: Case study of a bespoke service provider. Procedia Manufacturing, 49, 185-192.

22. Li, Y., Jiang, W., Yang, L., \& Wu, T. (2018). On neural networks and learning systems for business computing. Neurocomputing, 275, 1150-1159.

23. Gustafsson, E., Jonsson, P., \& Holmström, J. (2019). Digital product fitting in retail supply chains: maturity levels and potential outcomes. Supply Chain Management: An International Journal.

24. Jakhar, S. K., Rathore, H., \& Mangla, S. K. (2018). Is lean synergistic with sustainable supply chain? An empirical investigation from emerging economy. Resources, Conservation and Recycling, 139, 262-269.

25. Gawankar, S. A., Gunasekaran, A., \& Kamble, S. (2020). A study on investments in the big datadriven supply chain, performance measures and organisational performance in Indian retail 4.0 context. International Journal of Production Research, 58(5), 1574-1593.

26. Rogers, D., \& Park, J.S. (2018). A Study on the Development of Logistics and Supply Chain Professionals in Australia. 물류학회지 제, 28(6), 135-145.

27. Shahzad, A., Zhang, K., \& Gherbi, A. (2020). Intuitive development to examine collaborative iot supply chain system underlying privacy and security levels and perspective powering through proactive blockchain. Sensors, 20(13), 3760.

28. Omoikhudu, J. (2017). The Impact of Training and Development on Employee Retention in the Retail Sector, an Examination of the Role of Coaching in a Leading Retailer in Dublin, Republic of Ireland. A Case Study of Mark and Spencer's Store Dublin (Doctoral dissertation, Dublin, National College of Ireland).

29. Gayen, D. K. (2017). Basic Factors for Developing Standard Scorecard for Performance and Efficiency Measurement for Organisations. Journal of Supply Chain Management Systems, 6(1).

30. Sinaga, H. D., \& Sinaga, B. R. (2018). Rekonstruksi Model-Model Pertanggungjawaban di Bidang Perpajakan dan Kepabeanan. PT. Kanisius. 
31. Sinaga, H. D., \& Sinaga, B. R. (2018). Rekonstruksi Model-Model Pertanggungjawaban di Bidang Perpajakan dan Kepabeanan. PT. Kanisius.

32. Mira, F., Purpari, G., Di Bella, S., Colaianni, M. L., Schirò, G., Chiaramonte, G., \& Guercio, A. (2019).
Spreading of canine parvovirus type $2 \mathrm{c}$ mutants of Asian origin in southern Italy. Transboundary and emerging diseases, 66(6), 2297-2304.

\section{APPENDIX}

\begin{tabular}{|c|c|c|c|}
\hline Year & Author & Article & Theme \\
\hline 2017 & $\begin{array}{l}\text { Loon, L.K., Udin, Z.M., } \\
\text { Hassan, M.G., Bakar, Z.A. and } \\
\text { Hanaysha, J.R., }\end{array}$ & $\begin{array}{l}\text { The power of organizational } \\
\text { innovativeness in shaping supply chain } \\
\text { operational performance. }\end{array}$ & $\begin{array}{l}\text { Importance of supply } \\
\text { chain in organisational } \\
\text { performances }\end{array}$ \\
\hline 2020 & $\begin{array}{l}\text { Farsi, M., Bailly, A., Bodin, D., } \\
\text { Penella, V., Pinault, P.L., } \\
\text { Nghia, E.T.T., Sibson, J. and } \\
\text { Erkoyuncu, J.A., }\end{array}$ & $\begin{array}{l}\text { An Optimisation Framework for } \\
\text { Improving Supply Chain Performance: } \\
\text { Case study of a bespoke service } \\
\text { provider. }\end{array}$ & $\begin{array}{l}\text { Importance of supply } \\
\text { chain optimisation } \\
\text { framework development }\end{array}$ \\
\hline 2019 & $\begin{array}{l}\text { Gustafsson, E., Jonsson, P. and } \\
\text { Holmström, J., }\end{array}$ & $\begin{array}{l}\text { Digital product fitting in retail supply } \\
\text { chains: maturity levels and potential } \\
\text { outcomes. }\end{array}$ & $\begin{array}{l}\text { Supply chain and product } \\
\text { characteristics }\end{array}$ \\
\hline 2020 & $\begin{array}{l}\text { Gawankar, S.A., Gunasekaran, } \\
\text { A. and Kamble, S., }\end{array}$ & $\begin{array}{l}\text { A study on investments in the big } \\
\text { data-driven supply chain, performance } \\
\text { measures and organisational } \\
\text { performance in Indian retail } 4.0 \\
\text { context. }\end{array}$ & $\begin{array}{l}\text { Impact of supply chain } \\
\text { performance measures on } \\
\text { organisational } \\
\text { performance }\end{array}$ \\
\hline 2018 & Rogers, D. and Park, J.S., & $\begin{array}{l}\text { A Study on the Development of } \\
\text { Logistics and Supply Chain } \\
\text { Professionals in Australia. }\end{array}$ & $\begin{array}{l}\text { Effective skills and } \\
\text { competencies for the } \\
\text { supply chain } \\
\text { professionals }\end{array}$ \\
\hline 2020 & $\begin{array}{l}\text { Shahzad, A., Zhang, K. and } \\
\text { Gherbi, A., }\end{array}$ & $\begin{array}{l}\text { Intuitive development to examine } \\
\text { collaborative iot supply chain system } \\
\text { underlying privacy and security levels } \\
\text { and perspective powering through } \\
\text { proactive blockchain. }\end{array}$ & $\begin{array}{l}\text { Security and privacy of } \\
\text { the supply chain network }\end{array}$ \\
\hline 2017 & Omoikhudu, J., & $\begin{array}{l}\text { The Impact of Training and } \\
\text { Development on Employee Retention } \\
\text { in the Retail Sector, an Examination of } \\
\text { the Role of Coaching in a Leading } \\
\text { Retailer in Dublin, Republic of Ireland. } \\
\text { A Case Study of Mark and Spencer's } \\
\text { Store Dublin (Doctoral dissertation, }\end{array}$ & $\begin{array}{l}\text { Importance of training } \\
\text { and development } \\
\text { programme in the } \\
\text { organisation }\end{array}$ \\
\hline 2017 & Gayen, D.K., & $\begin{array}{l}\text { Basic Factors for Developing Standard } \\
\text { Scorecard for Performance and } \\
\text { Efficiency Measurement for } \\
\text { Organisations. }\end{array}$ & $\begin{array}{l}\text { Criteria for measuring the } \\
\text { performances in the } \\
\text { organisation in supply- } \\
\text { chain area }\end{array}$ \\
\hline
\end{tabular}

